\title{
Effect of Delayed Harvest and Fungicide Sprays on Pigeon Pea Seed Quality in Puerto Rico'
}

\author{
M. A. Ellis, H. C. Minor, R. Abrams, and F. J. Julia ${ }^{2}$ \\ ABSTRACT
}

Pigeon pea (Cajanus cajan cv. 3B-Bushy) seeds were harvested at maturity and 1,2 or 3 weeks after maturity (delayed harvests) from nonsprayed plants or from plants sprayed with maneb, benomyl, or a combination of the two at four 1 -week intervals beginning 110 days after planting. At each harvest date, the decrease in percentage germination and emergence and the increase in seedborne fungi was significantly less for seeds from benomyl-sprayed plants than from nonsprayed plants or those sprayed with maneb. The percentage seed germination in vitro and field emergence decreased and the percentage of internally seedborne fungi increased with each delay in harvest for all treatments. There were no significant differences in total internally seedborne fungi, germination in vitro, or field emergence between plants sprayed with maneb alone and the nontreated control. When harvested at maturity, plants of all treatments produced good quality seeds (over $85 \%$ germination).

\section{INTRODUCTION}

Studies on soybean (Glycine max (L.) Merr.) have shown that a delay in harvest date past maturity results in an increased percentage of seeds infected by fungi, and a reduced percentage seed germination in vitro and emergence in the field $(4,7)$. Phomopsis sp. is one of the most common internally seedborne fungi associated with delayed harvest of soybean. The percentage incidence of seedborne Phomopsis sp. has been negatively correlated with percentage field emergence $(3,4)$. Ellis and Sinclair (5) reported that $\mathrm{MBC}$ (methyl 2-benzimidozolecarbamate), the fungitoxic breakdown product of benomyl (methyl 1-(butylcarbamoyl)-2-benzimidozolecarbamate) was recovered from soybean seeds of plants sprayed with foliar applications of benomyl. Seeds from sprayed plants which were harvested 4 weeks after maturity had a significantly higher percentage seed germination and field emergence, and significantly less total internally seedborne fungi and Phomopsis spp. than seeds from nonsprayed plants. The results of similar studies conducted on dry bean (Phaseolus vulgaris) are very similar to those reported for soybean (2).

One of the factors limiting increased production of pigeon pea (Cajanus cajan) in Puerto Rico is poor seed germination and emergence in the field. In 1976 commercial plantings in cooperation with local growers, field emergence in 4 -ha fields ranged from $28-45 \%$. In vitro germination,

\footnotetext{
' Manuscript submitted to Editorial Board October 4, 1978.

${ }^{2}$ First author Department of Crop Protection, University of Puerto Rico, Mayaguez, second author, Department of Agronomy, University of Missouri, Columbia; third and fourth authors Agricultural Experimental Station, University of Puerto Rico, Mayagüez, P.R. The authors wish to thank Eileen Rosario for technical assistance.
} 
percentage and incidence of internally seedborne fungi of seeds used in planting these fields were 60 and $75 \%$, respectively (1). In order to increase the commercial production of pigeon pea, a source of high quality disease-free seeds must be established. Factors affecting seed infection by fungi in the field need to be studied and methods of controlling internally seedborne fungi need to be developed and applied.

This study reports on the effect of delayed harvest date (time in the field past maturity), and foliar applications of fungicides on pigeon pea seed infected by fungi in the field, and seed germination and field emergence.

\section{MATERLALS AND METHODS}

A plot of pigeon pea (cv. 2B-Bushy) was planted at the Isabela substation of the University of Puerto Rico Agricultural Experiment Station on October 15, 1976. Rows were $6 \mathrm{~m}$ long on 61-cm centers with 4 rows per plot. Plant stands were thinned to 10 plants per meter. Treated plots were sprayed four times at 1-week intervals starting 110 days after planting, with either benomyl (Benlate 50 WP, E. I. du Pont de Nemours and Co., Wilmington, Delaware) ${ }^{3}(1.14 \mathrm{~kg}$ a.i./ha); maneb (manganese ethylenebisdithiocarbamate, Manzate 80 WP, E. I. du Pont de Nemours and Co.) (1.82 kg a.i./ha); maneb + benomyl $(0.91+0.57 \mathrm{~kg}$ a.i. $/ \mathrm{ha}$, respectively); or maneb + benomyl $(1.82+1.14 \mathrm{~kg}$ a.i./ha, respectively). Sprays were applied with a hand sprayer. Nontreated plots served as controls. Each treatment was replicated four times in a randomized complete block design.

Seeds from one row of each sprayed and nonsprayed plot were harvested at maturity (first harvest) on February 28, 1977. One of the remaining three rows per plot was harvested at 1,2 and 3 weeks after maturity (delayed harvests). All seeds were dried to $12-13 \%$ moisture and stored at $10^{\circ} \mathrm{C}$ until assayed in the laboratory or planted in the field.

The experiment was planted a second time at the Isabela substation on July 11, 1977. Mixtures of benomyl + maneb were not included among the treatments in the second year of the experiment. All other procedures were as previously described.

One-hundred seeds from each replication per treatment and harvest date for both plantings were bioassayed for incidence of internally seedborne fungi and percentage germination in vitro. All seeds were surface disinfested by being soaked in a $0.25 \%$ sodium hypochlorite solution for $2.5 \mathrm{~min}$, and then in $70 \%$ ethanol for $2 \mathrm{~min}$, and finally rinsed in sterile

\footnotetext{
${ }^{3}$ Trade names in this publication are used only to provide specific information. Mention of a trade name does not constitute a warranty of equipment or materials by the Agricultural Experiment Station of the University of Puerto Rico, nor is this mention a statement of preference over other equipment or materials.
} 
distilled water. Seeds were then plated on Gibco potato dextrose agar (PDA) in culture dishes. The percentages of germination and incidence of fungi were recorded after 7 days at $25^{\circ}$ C. A seed was considered germinated when the radicle was 1.5 times the length of the cotyledons.

An additional 100 seeds from each replication per treatment and harvest date for both dates of planting were planted in the field at the Isabela substation. Seeds were planted in $3 \mathrm{~m}$ rows on 61 -cm centers in

TABLE 1.-Mean percentage germination in culture plates, field emergence and total percentage of seeds with internally seedborne fungi of pigeon pea from plants sprayed with maneb or benomyl alone and in combination during 1976 and harvested at four weekly intervals beginning at maturity

\begin{tabular}{|c|c|c|c|c|}
\hline \multirow{2}{*}{$\begin{array}{c}\text { Treatment and rate in } \mathrm{kg} \\
\mathrm{a} . \mathrm{i} / \mathrm{ha} \mathrm{a}^{\prime}\end{array}$} & \multirow{2}{*}{$\begin{array}{l}\text { Harvest after } \\
\text { maturity (in } \\
\text { weeks) }\end{array}$} & \multicolumn{3}{|c|}{ Mean percentage ${ }^{2}$} \\
\hline & & Germination & Emergence & Fungi \\
\hline \multirow[t]{4}{*}{ Maneb (1.82) } & 0 & 88.7 & 75.7 & 29.7 \\
\hline & 1 & 77.5 & 67.0 & 58.5 \\
\hline & 2 & 60.8 & 57.3 & 76.2 \\
\hline & 3 & 54.8 & 51.0 & 91.5 \\
\hline \multirow[t]{4}{*}{ Benomyl (1.14) } & 0 & 91.7 & 85.5 & 21.0 \\
\hline & 1 & 88.0 & 87.0 & 33.5 \\
\hline & 2 & 83.2 & 83.7 & 52.5 \\
\hline & 3 & 73.7 & 70.0 & 75.5 \\
\hline Maneb (0.91) & 0 & 93.2 & 89.0 & 19.8 \\
\hline+ & 1 & 87.7 & 87.7 & 34.3 \\
\hline \multirow[t]{2}{*}{ Benomyl (0.57) } & 2 & 83.0 & 84.5 & 52.0 \\
\hline & 3 & 71.3 & 72.3 & 75.0 \\
\hline Maneb (1.82) & 0 & 92.7 & 88.3 & 19.8 \\
\hline+ & 1 & 86.7 & 87.7 & 34.0 \\
\hline \multirow[t]{2}{*}{ Benomyl (1.14) } & 2 & 82.3 & 84.2 & 54.0 \\
\hline & 3 & 73.7 & 74.5 & 74.8 \\
\hline \multirow[t]{4}{*}{ Nontreated } & 0 & 87.8 & 73.5 & 30.8 \\
\hline & 1 & 77.7 & 65.5 & 61.5 \\
\hline & 2 & 59.5 & 55.8 & 75.3 \\
\hline & 3 & 52.3 & 48.5 & 91.5 \\
\hline \multirow{3}{*}{\multicolumn{2}{|c|}{$\begin{array}{c}\text { LSD (.05) - Between harvests } \\
\text { within treatments } \\
\text { - Between treatments } \\
\text { within harvests }\end{array}$}} & & & \\
\hline & & 2.86 & 2.41 & 3.99 \\
\hline & & 2.96 & 3.65 & 3.81 \\
\hline
\end{tabular}

${ }^{1}$ Benomyl $=$ methyl 1 (butylcarbamoyl-2-benzimidazolecarbamate as Benlate 50 WP; maneb $=$ manganese ethylenebisdithiocarbamate as manzate $80 \mathrm{WP}$; a.i. = active ingredient.

${ }^{2}$ Based on four replications of 100 seeds from each treatment and harvest date.

a randomized complete block design. Emergence in the field was recorded after 20 days. Analysis of variance was conducted on all data.

\section{RESULTS}

\section{GERMINATION IN VITRO AND FIELD EMERGENCE}

At maturity in 1976, seeds from plants sprayed with benomyl (alone or in combination with maneb) had a significantly higher percentage ger- 
mination in vitro and emergence in the field than seeds from nontreated plants or plants treated with maneb alone (table 1). In 1977, there were no significant differences between treatments for percentage germination and field emergence of seeds at maturity (table 2).

Percentage germination in vitro significantly decreased for seeds from all treatments with each delay in harvest date during both planting seasons. All treatments containing benomyl had a significantly higher percentage seed germination than those with maneb alone, or nontreated plants, for all delayed harvest dates during both planting seasons. There was no significant difference in percentage germination between seeds from plants sprayed with maneb and those of the nontreated control.

TABLE 2.-Mean percentage germination in culture plates, field emergence and total percentage of seeds with internally seedborne fungi of pigeon pea from plants sprayed with maneb or benomyl during 1977 and harvested at four weekly intervals beginning at maturity

\begin{tabular}{|c|c|c|c|c|c|}
\hline \multirow{2}{*}{\multicolumn{2}{|c|}{$\begin{array}{c}\text { Treatment and rate in } \mathrm{kg} \\
\text { a.i./ha }\end{array}$}} & \multirow{2}{*}{$\begin{array}{l}\text { Harvest after } \\
\text { maturity (in } \\
\text { weeks) }\end{array}$} & \multicolumn{3}{|c|}{ Mean percentage $^{2}$} \\
\hline & & & Germination & Emergence & Fungi \\
\hline \multirow{4}{*}{\multicolumn{2}{|c|}{ Maneb (1.82) }} & 0 & 93.8 & 91.8 & 10.0 \\
\hline & & 1 & 84.0 & 83.3 & 21.8 \\
\hline & & 2 & 75.6 & 76.3 & 30.3 \\
\hline & & 3 & 69.3 & 68.0 & 38.0 \\
\hline \multirow{4}{*}{\multicolumn{2}{|c|}{ Benomyl (1.14) }} & 0 & 95.0 & 93.7 & 6.5 \\
\hline & & 1 & 90.2 & 89.5 & 13.5 \\
\hline & & 2 & 84.5 & 86.3 & 21.8 \\
\hline & & 3 & 80.3 & 79.8 & 28.3 \\
\hline \multirow{4}{*}{\multicolumn{2}{|c|}{ Nontreated }} & 0 & 95.0 & 92.5 & 11.5 \\
\hline & & 1 & 84.8 & 83.5 & 22.0 \\
\hline & & 2 & 77.0 & 77.8 & 29.8 \\
\hline & & 3 & 69.8 & 67.0 & 38.0 \\
\hline \multicolumn{6}{|c|}{ LSD (.05) - Between harvests } \\
\hline \multicolumn{3}{|c|}{$\begin{array}{l}\text { within treatments } \\
\text { - Between treatments }\end{array}$} & 2.14 & 2.18 & 2.25 \\
\hline \multicolumn{3}{|c|}{ within harvests } & 2.04 & 2.42 & 2.17 \\
\hline
\end{tabular}

${ }^{\prime}$ Benomyl = methyl 1 (butylcarbamoyl-2-benzimidazolecarbamate as Benlate $50 \mathrm{WP}$; maneb $=$ manganese ethylenebisdithiocarbamate as manzate $80 \mathrm{WP} ;$ a.i. = active ingredient.

${ }^{2}$ Based on four replications of 100 seeds from each treatment and harvest date.

The data obtained for percentage emergence in the field was very similar to that for percentage germination in vitro (tables 1 and 2).

\section{INTERNALLY SEEDBORNE FUNGI}

The following genera of fungi were recovered from seeds of this study: Aspergillus sp.; Alternaria tenuissima; Cladosporium sp.; Fusarium semitectum; Lasiodiplodia theobromae; Penicillium sp.; and Phomopsis sp. At maturity, seeds from all plants sprayed with benomyl had siginficantly fewer internally seedborne fungi than did seeds from nontreated 
plants or those sprayed with maneb alone (tables 3 and 4). There were no significant differences in percentage total fungi among seeds from plants sprayed with maneb alone and nontreated plants.

The percentage of internally seedborne fungi significantly increased with each week's delay in harvest date for all treatments and growing seasons. All treatments containing benomyl had seeds with significantly

Table 3.-Alternaria (Alt.), Fusarium (Fus.), Lasiodiplodia (Las.), Phomopsis (Phom.), and miscellaneous (Mis.) species recovered from pigeon pea seeds from plants sprayed with maneb or benomyl alone and in combination during 1976 and harvested at four weekly intervals beginning at maturity

\begin{tabular}{|c|c|c|c|c|c|c|}
\hline \multirow{2}{*}{$\begin{array}{l}\text { Treatment and rate in } \\
\text { kg a.i./ha }\end{array}$} & \multirow{2}{*}{$\begin{array}{l}\text { Harvest after ma- } \\
\text { turity (in weeks) }\end{array}$} & \multicolumn{5}{|c|}{ Mean percentage $\cdot$ recovery ${ }^{2}$} \\
\hline & & Alt. & Fus. & Las. & Phom. & Mis. \\
\hline \multirow[t]{4}{*}{ Maneb (1.82) } & 0 & 11.0 & 4.7 & 6.3 & 6.7 & 0.7 \\
\hline & 1 & 22.8 & 6.0 & 15.8 & 12.8 & 1.3 \\
\hline & 2 & 22.0 & 5.8 & 25.7 & 22.0 & 0.8 \\
\hline & 3 & 23.7 & 8.0 & 32.5 & 27.3 & 0.0 \\
\hline \multirow[t]{4}{*}{ Benomyl (1.14) } & 0 & 14.5 & 2.0 & 1.5 & 1.0 & 2.0 \\
\hline & 1 & 22.3 & 2.0 & 5.0 & 2.5 & 1.8 \\
\hline & 2 & 32.5 & 3.5 & 10.0 & 5.0 & 1.5 \\
\hline & 3 & 39.5 & 10.0 & 14.0 & 10.0 & 1.0 \\
\hline Maneb (.091) & 0 & 12.5 & 2.0 & 1.7 & 2.0 & 1.8 \\
\hline+ & 1 & 22.8 & 3.0 & 4.3 & 2.0 & 2.3 \\
\hline \multirow{2}{*}{ Benomyl (0.57) } & 2 & 31.0 & 3.3 & 10.3 & 6.0 & 1.5 \\
\hline & 3 & 39.5 & 7.5 & 14.5 & 12.5 & 1.0 \\
\hline Maneb (1.82) & 0 & 11.5 & 1.2 & 2.0 & 1.0 & 4.0 \\
\hline+ & 1 & 24.8 & 2.0 & 4.7 & 2.2 & 0.3 \\
\hline \multirow{2}{*}{ Benomyl (1.14) } & 2 & 32.8 & 3.3 & 9.5 & 6.3 & 2.3 \\
\hline & 3 & 38.3 & 9.0 & 14.3 & 11.3 & 2.0 \\
\hline \multirow[t]{4}{*}{ Nontreated } & 0 & 9.2 & 7.3 & 5.0 & 5.0 & 4.3 \\
\hline & 1 & 20.0 & 8.3 & 21.3 & 8.5 & 3.5 \\
\hline & 2 & 20.5 & 6.7 & 27.0 & 20.5 & 0.5 \\
\hline & 3 & 22.5 & 10.8 & 32.0 & 24.8 & 1.5 \\
\hline \multicolumn{7}{|c|}{ LSD (.05) - Between harvests } \\
\hline \multicolumn{2}{|c|}{$\begin{array}{l}\text { within treatments } \\
\text { - Between treatments }\end{array}$} & 2.58 & 1.76 & 1.34 & 1.40 & 2.56 \\
\hline \multicolumn{2}{|c|}{ within harvests } & 2.57 & 1.91 & 1.47 & 1.43 & 2.55 \\
\hline
\end{tabular}

${ }^{\prime}$ Benomyl $=$ methyl 1 (butylcarbamoyl-2-benzimidazolecarbamate as Benlate $50 \mathrm{WP}$; maneb = manganese ethylenebisdithiocarbamate as manzate $80 \mathrm{WP} ;$ a $\mathbf{i} .=$ active ingredient.

${ }^{2}$ Based on four replications of 100 seeds from each treatment and harvest date.

fewer fungi than did nontreated plants or those sprayed with maneb alone.

The percentage incidence of internally seedborne $A$. tenuissima, $L$. theobromae, and Phomopsis sp. significantly increased with each week's delay in harvest date for all treatments. Seeds infected with $L$. theobromae and Phomopsis sp. rarely germinated. L. theobromae was not 
recovered from seeds produced in 1977. Seeds from treatments containing benomyl had significantly less $L$. theobromae and Phomopsis sp. than those containing maneb and the nontreated control for all harvest dates. There were no significant differences between the percentage incidence of L. theobromae and Phomopsis sp. from seeds of plants sprayed with maneb and those of the nontreated control. Benomyl appeared to give good control of $F$. semitectum for up to 2 weeks after maturity in 1976, and for up to 3 weeks after maturity in 1977. Maneb appeared to give some control of $F$. semitectum (table 3 ).

TABle 4.-Alternaria (Alt.), Fusarium (Fus.), Phomopsis (Phom.) and miscellaneous

(Mis.) species recovered from pigeon pea seeds from plants sprayed with maneb or benomyl during 1977 and harvested at four weekly intervals beginning at maturity

\begin{tabular}{|c|c|c|c|c|c|}
\hline \multirow{2}{*}{$\begin{array}{c}\text { Treatment and rate in } \\
\text { kg a.i./ha }\end{array}$} & \multirow{2}{*}{$\begin{array}{l}\text { Harvest after ma- } \\
\text { turity (weeks) }\end{array}$} & \multicolumn{4}{|c|}{ Mean percentage recovery ${ }^{2}$} \\
\hline & & Alt. & Fus. & Phom. & Mis. \\
\hline \multirow[t]{4}{*}{ Maneb (1.82) } & 0 & 3.3 & 2.3 & 3.5 & 1.0 \\
\hline & 1 & 4.8 & 6.5 & 9.5 & 1.0 \\
\hline & 2 & 8.0 & 6.0 & 16.0 & 0.3 \\
\hline & 3 & 11.8 & 6.8 & 19.5 & 0.0 \\
\hline \multirow[t]{4}{*}{ Benomyl (1.14) } & 0 & 5.0 & 0.0 & 0.5 & 1.0 \\
\hline & 1 & 9.0 & 1.3 & 1.5 & 1.8 \\
\hline & 2 & 15.3 & 1.5 & 5.0 & 0.2 \\
\hline & 3 & 18.3 & 1.5 & 7.8 & 0.8 \\
\hline \multirow[t]{4}{*}{ Nontreated } & 0 & 4.0 & 2.8 & 4.5 & 0.3 \\
\hline & 1 & 5.0 & 6.0 & 10.3 & 0.8 \\
\hline & 2 & 6.5 & 5.8 & 17.5 & 0.0 \\
\hline & 3 & 10.5 & 7.0 & 20.5 & 0.0 \\
\hline \multirow{4}{*}{\multicolumn{2}{|c|}{$\begin{array}{c}\text { LSD (0.5) - Between harvests } \\
\text { within treatments } \\
\text { - Between treatments } \\
\text { within harvests }\end{array}$}} & & & & ns \\
\hline & & 1.88 & 1.57 & 1.94 & \\
\hline & & & & & $\mathrm{ns}$ \\
\hline & & 1.91 & 1.58 & 1.89 & \\
\hline
\end{tabular}

${ }^{1}$ Benomyl $=$ methyl 1 (butylcarbamoyl-2-benzimidazolecarbamate as Benlate $50 \mathrm{WP}$; maneb $=$ manganese ethylenebisdithiocarbamate as manzate $80 \mathrm{WP}$; a.i. = active ingredient.

${ }^{2}$ Based on four replications of 100 seeds from each treatment and harvest date.

After 3 weeks of delayed harvest, seeds from all treatments containing benomyl had a significantly higher percentage of seedborne $A$. tenuissima than seeds from plants sprayed with maneb or the nontreated control. However, A. tenuissima appeared to have little effect on pigeon pea germination in vitro.

When in vitro germination and emergence in the field were correlated with the incidence of total internally seedborne fungi, A. tenuissima, $F$. semitectum, L. theobromae and Phomposis sp., the following correlation coefficients were found: $-.927 ;-.325 ;-.691 ;-.957$; and -.959 , respectively, for in vitro germination, and $-.818 ;-.064 ;-.749 ;-.928$; and -.933 , 
respectively, for field emergence. All correlation coefficients, except those for A. tenuissima, were very significant (.01 level).

\section{DISCUSSION}

In vitro germination and field emergence of pigeon pea in Puerto Rico are markedly reduced when harvest is delayed past field maturity. The data obtained in this study indicate that internally seedborne fungi play a major role in this reduction in seed quality. The percentage seed infection by fungi increases with time in the field past maturity (delayed harvest). As the percentage incidence of total internally seedborne fungi, L. theobromae, and Phomopsis sp. increased, the percentage germination in vitro and field emergence decreased. Similar findings have been reported for soybean $(4,7)$ and dry bean $(2)$.

Foliar applications of benomyl appeared to suppress seed invasion by most fungi for up to 3 weeks. Benomyl had little or no effect on $A$. tenuissima. This is in part due to the resistance of Alternaria spp. to benomyl (6). When compared to benomyl, maneb had little effect on controlling seed infection by fungi. This could be partially due to the systemic nature of benomyl. Maneb (a nonsystemic fungicide) can be washed off by rain, whereas benomyl can move into plant tissues.

The use of fungicides on commercial plantings of pigeon pea may not be economically feasible. Alternative measures for controlling internally seedborne fungi need to be sought. When harvested at maturity, all plants used in this study produced good quality seed (over $85 \%$ germination) in both growing seasons. This emphasizes the importance of timely harvest in the production of high quality pigeon pea seed. Harvesting seed production fields immediately at maturity requires no additional production cost and will result in higher quality seed.

\section{RESUMEN}

Las semillas del gandul (Cajanus cajan cv. 2B-Bushy) se cosecharon en la etapa de madurez y después de 1,2 , y 3 semanas de esta etapa, de plantas asperjadas y no asperjadas con maneb, benomyl o una combinación de ambos fungicidas. Se asperjaron cuatro veces a intervalos de una semana, comenzando a los 110 días de sembradas. En todos los tratamientos y con cada cosecha tardía, el porcentaje de germinación in vitro de las semillas y el de brotar en el campo disminuyó y el porcentaje de hongos internos en las semillas aumentó. En cada cosecha la disminución en el porcentaje de germinación, la brotadura y el aumento en los hongos internos en las semillas, fue significativamente menor en las semillas de plantas asperjadas con benomyl, que el de las que no se asperjaron o las asperjadas con maneb. No hubo diferencias significativas en el total de hongos internos en las semillas, germinación 
in vitro o de brotadura en el campo entre las plantas asperjadas con maneb y las no asperjadas. En todos los tratamientos cosechados en la etapa de madurez, las plantas produjeron semillas de buena calidad (sobre $85 \%$ de germinación).

\section{LITERATURE CITED}

I. Ellis, M. A., Foor, S. R., and Meléndez, P. L., Effect of internally seedborne fungi on germination of pigeon pea in Puerto Rico, (Abstr.) Mem. Soc. Puertorriqueña Ciencias Agrícolas 2: 8-9, 1977.

2. - Galvez, G. E., and Sinclair, J. B., Effect of foliar applications of systemic fungicides and late harvest on seed quality of dry bean (Phaseolus vulgaris), Plant Dis. Rep. 60: 1073-1076, 1976.

3. - Machado, C. D., Prasartsee, C., and Sinclair, J. B., Occurrence of Diaporthe phaseolorum var. sojae (Phomopsis sp.) in various soybean seed lots, Plant Dis. Rep. 58: $173-176,1974$.

4. and Sinclair, J. B., Effect of benomyl sprays on internally-borne fungi, germination, and emergence of late-harvested soybean seeds, Phytopathology 66: 680-682, 1976.

5. — and —, Movement of Methyl 2-Benzimidazolecarbamate into soybean seeds after foliar applications of benomyl, phytopathology 65: 1387-1389, 1975.

6. Ponchet, J. and Tramier, R., Effects du benomyl sur la croissance de l'oeillet et la microflore des sols trailes, Ann. Phytopathol. 3: 401-406, 1971.

7. Wilcox, J. R., Laviolette, F. A., and Athow, K. L. Deterioration of soybean seed quality associated with delayed harvest, Plant Dis. Rep. 58: 130-133, 1974. 